\title{
Pengaruh Indeks Massa Tubuh terhadap Respon Klopidogrel pada Pasien Sindrom Koroner Akut dengan Intervensi Koroner Perkutan di RSUPN Dr. Cipto Mangunkusumo Jakarta
}

\author{
Marlina Q. Aini ${ }^{1}$, Retnosari Andrajati ${ }^{1}$, Rina Mutiara ${ }^{2}$ \\ ${ }^{1}$ Fakultas Farmasi, Universitas Indonesia, Depok, Indonesia \\ ${ }^{2}$ Instalasi Farmasi RSUPN Dr. Cipto Mangunkusumo, Jakarta, Indonesia
}

\begin{abstract}
Abstrak
Tindakan Intervensi Koroner Perkutan (IKP) memiliki risiko trombosis yang menyebabkan gangguan kardiovaskular. Gangguan kardiovaskular dievaluasi dengan menggunakan Major Adverse Cardiac Event (MACE). Terapi pencegahan trombosis menggunakan dual antiplatelet, yakni asetosal dan klopidogrel. Klopidogrel merupakan obat dengan variabilitas farmakokinetik dan farmakodinamik yang tinggi pada setiap individu, salah satunya dipengaruhi oleh Indeks Massa Tubuh (IMT). Subjek dengan nilai IMT $\geq 25 \mathrm{~kg} / \mathrm{m}^{2}$ memiliki nilai agregasi platelet lebih besar dibanding subjek dengan IMT $<25 \mathrm{~kg} / \mathrm{m}^{2}$. Penggunaan klopidogrel di Indonesia tidak mempertimbangkan IMT. Penelitian ini bertujuan untuk mengetahui respon klopidogrel terhadap IMT pada pasien Sindrom Koroner Akut (SKA) dengan tindakan IKP. Penelitian dilakukan di RSUPN Dr. Cipto Mangunkusumo Jakarta dengan menggunakan data rekam medis tahun 2018. Subjek dikelompokkan berdasarkan IMT, yakni IMT $<25 \mathrm{~kg} / \mathrm{m}^{2}$ dan IMT $\geq 25 \mathrm{~kg} / \mathrm{m}^{2}$. Hasil analisis bivariat menunjukkan hubungan bermakna antara IMT dan MACE $(p=0,006)$. Analisis multivariat menunjukkan IMT merupakan satu-satunya variabel yang berhubungan dengan MACE $(p=0,002)$. Tidak ada variabel perancu yang bermakna terhadap MACE pada analisis bivariat dan multivariat. Semakin tinggi IMT, kemungkinan terjadinya MACE semakin besar. Relative risk (RR) yang diperoleh adalah 2,946. Simpulan penelitian ini adalah pasien dengan nilai IMT $\geq 25 \mathrm{~kg} / \mathrm{m}^{2}$ memiliki respon lebih rendah terhadap klopidogrel.
\end{abstract}

Kata kunci: IKP stent, indeks massa tubuh, klopidogrel

\section{Impact of Body Mass Index on Clopidogrel Responses after Percutaneous Coronary Intervention in Acute Coronary Syndrome Patients at Dr. Cipto Mangunkusumo Hospital Jakarta}

\begin{abstract}
Percutaneous Coronary Interventions (PCI) is revascularization strategy in acute coronary syndrome. One of PCI adverse effects is thrombosis which leads to Major Adverse Cardiovascular Events (MACE). The pharmacological therapy of dual antiplatelet, aspirin and clopidogrel, is important to reduce thrombosis after PCI. Clopidogrel is drug with high individual variability in pharmacokinetic and pharmacodynamic; one of factors contributing to the variability is body mass index (BMI). Previous studies showed that patient with BMI $\geq 25 \mathrm{~kg} / \mathrm{m}^{2}$ had higher platelet aggregation than patient with BMI $<25 \mathrm{~kg} / \mathrm{m}^{2}$. Dose adjustment based on body mass index is not implemented yet in Indonesia. The aim of this study was to assess the impact of body mass index on clopidogrel responses after PCI. This cohort retrospective study was conducted in Dr. Cipto Mangunkusumo Hospital Jakarta using patient medical records of year 2018. Patients were randomly assigned into two groups: BMI $<25 \mathrm{~kg} / \mathrm{m}^{2}$ and BMI $\geq 25 \mathrm{~kg} / \mathrm{m}^{2}$. Results of this study were: a) Bivariate analysis showed that BMI was significantly associated to MACE $(p=0.006)$; b) Multivariate analysis showed that BMI was the only variable significantly correlated with MACE ( $p=0.002)$; $)$ No confounder variables were correlated with MACE in bivariate and multivariate analysis; and d) Higher BMI indicated higher risk of MACE with relative risk (RR) 2.946. To conclude, patient with $\mathrm{BMI} \geq 25 \mathrm{~kg} / \mathrm{m}^{2}$ have lower clopidogrel response.
\end{abstract}

Keywords: Body mass index, clopidogrel, PCI stent

Korespondensi: Marlina Q. Aini, S.Farm., Apt., Fakultas Farmasi Universitas Indonesia, Depok, Jawa Barat 16424, Indonesia, email: marlina.apt@gmail.com

Naskah diterima: 12 April 2019, Diterima untuk diterbitkan: 27 Agustus 2019, Diterbitkan: 28 September 2019 


\section{Pendahuluan}

Sindrom koroner akut (SKA), gejala akut dari penyakit jantung iskemik, merupakan penyebab kematian dan kecacatan tertinggi di dunia maupun di Indonesia. Salah satu penanganan SKA yaitu melalui tindakan Intervensi Koroner Perkutan (IKP), baik menggunakan stent atau tidak. Tindakan IKP mempunyai risiko berupa trombosis yang dapat menyebabkan berbagai macam gangguan jantung dan pembuluh darah lainnya. Trombosis terjadi disebabkan adanya gangguan mekanik pada plak dan pembuluh darah saat proses IKP yang mengaktivasi sistem koagulasi. ${ }^{1}$ Gangguan jantung karena adanya trombosis setelah tindakan IKP dievaluasi menggunakan luaran Major Adverse Cardiac Event (MACE). MACE merupakan segala kejadian yang berhubungan dengan penyakit kardiovaskular, yang menyebabkan kematian atau menyebabkan pasien masuk rumah sakit kembali. MACE terdiri atas gagal jantung, infark miokardium (fatal dan nonfatal), angina, tindakan IKP ulang atau coronary artery bypass graft, strok atau Transient Ischemic Attack (TIA) dan kematian., ${ }^{2,3}$ Faktor-faktor prosedural yang memengaruhi MACE setelah IKP antara lain jenis stent, jumlah stent dan total panjang stent. ${ }^{4-6}$ Faktor-faktor individu yang dapat memengaruhi MACE antara lain riwayat diabetes, riwayat hipertensi, status merokok atau tidak, obesitas, aktivitas fisik rendah dan riwayat hiperlipidemia., ${ }^{3,711}$ Terapi pencegahan terjadinya trombosis setelah IKP adalah penggunaan dual antiplatelet, yakni asetosal dan agen penghambat P2Y12 yakni klopidogrel. ${ }^{12,13}$

Klopidogrel merupakan obat yang mempunyai variabilitas farmakokinetik dan farmakodinamik tinggi pada setiap individu. Beberapa penelitian menunjukkan bahwa respon klopidogrel dipengaruhi oleh usia, jenis kelamin, Indeks Massa Tubuh (IMT), berat badan, polimorfisme genetik dan interaksi obat. ${ }^{14}$ Penelitian menunjukkan IMT secara signifikan memengaruhi respon klopidogrel. Subjek dengan IMT $\geq 25 \mathrm{~kg} / \mathrm{m}^{2}$, bioavaibilitas metabolit aktif klopidogrel lebih rendah serta reaktivitas platelet lebih tinggi. ${ }^{15}$ Klopidogrel hanya tersedia dalam kemasan dosis $75 \mathrm{mg}$ dan penyesuaian dosis terhadap IMT untuk pasien dewasa jarang dilakukan di Indonesia. Penelitian terkait pengaruh IMT terhadap respon klopidogrel pada pasien SKA dengan IKP perlu dilakukan di Indonesia. Penelitian ini bertujuan untuk mengevaluasi pengaruh IMT terhadap respon klopidogrel pada pasien SKA dengan prosedur IKP, dilihat dari luaran berupa kejadian Major Adverse Cardiac Event di RSUPN Dr. Cipto Mangunkusumo Jakarta.

\section{Metode}

Penelitian ini merupakan penelitian kuantitatif observasional dengan desain kohort retrospektif menggunakan data sekunder yakni data rekam medis tahun 2018. Penelitian dilaksanakan di Pelayanan Jantung Terpadu (PJT). RSUPN Dr. Cipto Mangunkusumo, Jakarta. Penelitian ini dinyatakan lolos kaji etik oleh Komite Etik Penelitian Kesehatan Fakultas Kedokteran Universitas Indonesia dengan nomor protokol 18-12-1385.

Populasi pada penelitian ini adalah pasien SKA dengan IKP yang mendapatkan dual antiplatelet, yakni asetosal dosis $80 \mathrm{mg}$ dan klopidogrel, selama minimal 60 hari di RSUPN Dr. Cipto Mangunkusumo Jakarta. Kriteria inklusi antara lain: 1) Pasien dewasa berusia 18-80 tahun; 2) Pasien dengan diagnosis SKA dengan IKP pemasangan stent; 3) Pasien yang melakukan pemasangan stent untuk pertama kali; 4) Pasien yang mendapatkan dosis muatan klopidogrel $300 \mathrm{mg}$ sebelum tindakan IKP; dan 5) Pasien yang mendapat terapi antiplatelet asetosal dosis $80 \mathrm{mg}$ dan klopidogrel 75 mg minimal 60 hari. Kriteria eksklusi antara lain: 1) Pasien dengan data rekam medis tidak lengkap; 2) Pasien rujuk balik setelah prosedur IKP; 3) Pasien dengan 
terapi antikoagulan sebagai obat pulang; 4) Pasien dengan terapi penghambat GP IIa/IIIb sebagai obat pulang; dan 5) Pasien dengan terapi inhibitor P2Y12 selain klopidogrel. Besaran sampel minimum dihitung dengan formula kohort dan diperoleh hasil sebanyak 60 sampel masing-masing kelompok.

Variabel bebas adalah IMT dan variabel terikat adalah MACE dalam 60 hari pertama. Variabel perancu yang dapat memengaruhi MACE adalah usia, jenis kelamin, jenis stent, jumlah stent, riwayat infark miokardium, komorbid diabetes melitus, perokok aktif, komorbid hipertensi, komorbid dislipidemia, komorbid gagal ginjal kronis, dan interaksi obat. Pada penelitian ini, digunakan kelompok terpajan atau kelompok pengamatan yaitu pasien SKA dengan IKP yang mendapatkan terapi dual antiplatelet dengan IMT $\geq 25 \mathrm{~kg} /$ $\mathrm{m}^{2}$. Kelompok tidak terpajan atau kelompok kontrol adalah pasien SKA dengan IKP yang mendapatkan terapi dual antiplatelet dengan IMT $<25 \mathrm{~kg} / \mathrm{m}^{2}$. Masing-masing kelompok tersebut ditelusuri adanya MACE dalam 60 hari pertama.

MACE merupakan segala kejadian yang berhubungan dengan penyakit kardiovaskular dan menyebabkan kematian pada pasien atau masuk rumah sakit kembali. Pada penelitian ini, subjek dikategorikan mengalami MACE apabila pasien masuk rumah sakit kembali tanpa rencana. Data MACE subjek diambil dari admisi melalui Instalasi Gawat Darurat (IGD) dalam 60 hari setelah pemasangan stent. Adapun pasien yang hanya melakukan kunjungan ke poliklinik tidak dimasukkan ke dalam kategori MACE. Kejadian-kejadian terkait kardiovaskular yang dimaksud adalah gagal jantung, infark miokardium (fatal dan nonfatal), angina, tindakan IKP ulang atau coronary artery bypass graft, strok atau TIA. Pada penelitian ini, digunakan analisis univariat untuk mengetahui gambaran dari demografi subjek, analisis bivariat Chi-Square untuk mengetahui hubungan antarvariabel, dan analisis multivariat regresi binomial untuk mengetahui pengaruh antarvariabel.

\section{Hasil}

Diperoleh sejumlah 124 rekam medik pasien SKA yang melakukan IKP. Rata-rata usia subjek penelitian adalah 58 tahun, dengan usia termuda adalah 36 tahun dan tertua 79 tahun. Rata-rata berat badan adalah 68,9 $\mathrm{kg}$, dengan berat badan tertinggi $110 \mathrm{~kg}$ dan terendah $48 \mathrm{~kg}$. Rata-rata IMT adalah 25,9 $\mathrm{kg} / \mathrm{m}^{2}$, dengan IMT tertinggi $38,97 \mathrm{~kg} / \mathrm{m}^{2}$ dan IMT terendah $17,6 \mathrm{~kg} / \mathrm{m}^{2}$ (Tabel 1).

Gambaran demografi dari kelompok IMT $<25 \mathrm{~kg} / \mathrm{m}^{2}$ yaitu sebanyak $50 \%$ subjek berusia $<60$ tahun, 83,3\% berjenis kelamin laki-laki, $35 \%$ mempunyai riwayat infark miokardium sebelumnya, 38,3\% dengan komorbid diabetes melitus, $80 \%$ dengan komorbid hipertensi, $7 \%$ dengan komorbid gagal ginjal kronis, 40\% aktif merokok, 98,3\% menggunakan stent jenis Drug Eluting Stent (DES), 51,3\% memasang satu stent, $98,3 \%$ tidak berinteraksi dengan omeprazole dan $56,7 \%$ menggunakan klopidogrel generik. Sementara itu, gambaran demografi kelompok IMT $\geq 25 \mathrm{~kg} / \mathrm{m}^{2}$ adalah

Tabel 1 Karakteristik Pasien Sindrom Koroner Akut dengan Intervensi Koroner Perkutan di RSUPN Dr. Cipto Mangunkusumo Jakarta, 2018

\begin{tabular}{lccccc}
\hline \multicolumn{1}{c}{ Karakteristik } & $\mathbf{n}$ & Minimum & Maksimum & Rata-Rata & Standar Deviasi \\
\hline Usia (tahun) & 124 & 36,00 & 79,00 & 58,175 & 8,963 \\
Berat Badan $(\mathrm{kg})$ & 124 & 48,00 & 110,00 & 68,915 & 12,136 \\
Tinggi Badan $(\mathrm{m})$ & 124 & 1,40 & 1,75 & 1,63 & 0,071 \\
IMT $\left(\mathrm{kg} / \mathrm{m}^{2}\right)$ & 124 & 17,631 & 38,974 & 25,909 & 4,091 \\
\hline
\end{tabular}


sebanyak $60,9 \%$ subjek penelitian berusia $<60$ tahun, $85,9 \%$ berjenis kelamin laki-laki, 26,6\% dengan komorbid infark miokardium sebelumnya, $51,6 \%$ dengan komorbid diabetes melitus, 85,9\% dengan komorbid hipertensi, 17,2\% dengan komorbid gagal ginjal kronis, 35,9\% perokok aktif, $100 \%$ subjek menggunakan jenis stent DES, 53,1\% memasang satu buah stent, 93,8\% tidak berinteraksi dengan omeprazole, dan 54,7\% menggunakan klopidogrel generik (Tabel 2).

Hasil analisis bivariat dengan Chi-Square menunjukkan adanya hubungan bermakna antara IMT dengan kejadian MACE dengan nilai $\mathrm{p}=0,006(<0,05)$ (Tabel 3). Seluruh variabel perancu tidak memiliki hubungan

Tabel 2 Demografi Pasien Sindrom Koroner Akut dengan Intervensi Koroner Perkutan di RSUPN Dr. Cipto Mangunkusumo Jakarta, 2018

\begin{tabular}{|c|c|c|c|}
\hline \multirow{2}{*}{ Demografi } & IMT $<25 \mathrm{~kg} / \mathrm{m}^{2}$ & IMT $\geq 25 \mathrm{~kg} / \mathrm{m}^{2}$ & \multirow{2}{*}{ Nilai p } \\
\hline & $n(\%)$ & $\mathbf{n}(\%)$ & \\
\hline \multicolumn{4}{|l|}{ Usia } \\
\hline$<60$ tahun & $30(50,0)$ & $39(60,9)$ & \multirow[t]{2}{*}{0,296} \\
\hline$\geq 60$ tahun & $30(50,0)$ & $25(39,1)$ & \\
\hline \multicolumn{4}{|l|}{ Jenis Kelamin } \\
\hline Laki-laki & $50(83,3)$ & $55(85,9)$ & \multirow[t]{2}{*}{0,878} \\
\hline Perempuan & $10(16,7)$ & $9(14,1)$ & \\
\hline \multicolumn{4}{|l|}{ Riwayat Infark } \\
\hline Tidak ada & $39(65,0)$ & $47(73,4)$ & \multirow[t]{2}{*}{0,410} \\
\hline Ada & $21(35,0)$ & $17(26,6)$ & \\
\hline \multicolumn{4}{|l|}{ Diabetes Melitus } \\
\hline Tidak ada & $37(61,7)$ & $31(48,4)$ & \multirow[t]{2}{*}{0,194} \\
\hline Ada & $23(38,3)$ & $33(51,6)$ & \\
\hline \multicolumn{4}{|l|}{ Dislipidemia } \\
\hline Tidak ada & $24(40,0)$ & $30(46,9)$ & \multirow[t]{2}{*}{0,555} \\
\hline Ada & $36(60,0)$ & $34(53,1)$ & \\
\hline \multicolumn{4}{|l|}{ Hipertensi } \\
\hline Tidak ada & $12(20,0)$ & $9(14,1)$ & \multirow[t]{2}{*}{0,521} \\
\hline Ada & $48(80,0)$ & $55(85,9)$ & \\
\hline \multicolumn{4}{|l|}{ Gagal Ginjal Kronis } \\
\hline Tidak ada & $53(88,3)$ & $53(82,8)$ & \multirow[t]{2}{*}{0,537} \\
\hline Ada & $7(11,7)$ & $11(17,2)$ & \\
\hline \multicolumn{4}{|l|}{ Merokok } \\
\hline Tidak & $36(60,0)$ & $41(64,1)$ & \multirow[t]{2}{*}{0,779} \\
\hline Ya & $24(40,0)$ & $23(35,9)$ & \\
\hline \multicolumn{4}{|l|}{ Jenis Stent } \\
\hline Drug Eluting Stent (DES) & $59(98,3)$ & $64(100,0)$ & \multirow[t]{2}{*}{0,484} \\
\hline Bare Metal Stent (BMS) & $1(1,7)$ & $0(0,0)$ & \\
\hline \multicolumn{4}{|l|}{ Jumlah Stent } \\
\hline 1 stent & $31(51,3)$ & $34(53,1)$ & \multirow[t]{3}{*}{0,987} \\
\hline 2-3 stent & $28(46,7)$ & $29(45,3)$ & \\
\hline$>3$ stent & $1(1,7)$ & $1(1,6)$ & \\
\hline \multicolumn{4}{|c|}{ Interaksi dengan Proton Pump Inhibitor } \\
\hline Tidak ada & $59(98,3)$ & $60(93,8)$ & \multirow[t]{2}{*}{0,366} \\
\hline Ada & $1(1,7)$ & $4(6,3)$ & \\
\hline \multicolumn{4}{|l|}{ Jenis Klopidogrel } \\
\hline Plavix ${ }^{\circledR}$ & $26(43,3)$ & $29(45,3)$ & \multirow[t]{2}{*}{0,967} \\
\hline Generik & $34(56,7)$ & $35(54,7)$ & \\
\hline
\end{tabular}


Tabel 3 Hasil Tabulasi Silang Kategori Berat Badan dan MACE pada Pasien Sindrom Koroner Akut dengan Intervensi Koroner Perkutan di RSUPN Dr. Cipto Mangunkusumo Jakarta, 2018

\begin{tabular}{lccc}
\hline \multirow{2}{*}{ Kelompok } & Terdapat MACE & Tidak Terdapat MACE & \multirow{2}{*}{ Nilai p } \\
\cline { 2 - 3 } & $\mathbf{n}(\%)$ & $\mathbf{n}(\%)$ & \\
\hline IMT $<25 \mathrm{~kg} / \mathrm{m}^{2}$ & $7(11,7)$ & $53(88,3)$ & \multirow{2}{*}{0,006} \\
$\mathrm{IMT} \geq 25 \mathrm{~kg} / \mathrm{m}^{2}$ & $22(34,4)$ & $42(65,6)$ & \\
\hline
\end{tabular}

bermakna dengan kejadian MACE (Tabel 4). Analisis multivariat menunjukkan adanya pengaruh IMT terhadap kejadian MACE, dengan nilai $p=0,004(<0,05)$. IMT dan MACE memiliki hubungan sejalan, yakni semakin tinggi IMT, kemungkinan terjadi MACE juga semakin tinggi. Pada analisis multivariat, IMT adalah satu-satunya variabel yang berpengaruh terhadap MACE, seluruh variabel perancu tidak memiliki pengaruh bermakna terhadap MACE.

Dari 124 subjek, didapatkan 29 kejadian MACE, dengan waktu terjadi rata-rata 38 hari, waktu tercepat terjadinya MACE adalah 10 hari dan waktu terlambat adalah 60 hari. Nilai incidence rate MACE pada kelompok IMT $<25 \mathrm{~kg} / \mathrm{m}^{2}$ adalah 0,1167 , sedangkan nilai incidence rate MACE pada kelompok IMT $\geq 25 \mathrm{~kg} / \mathrm{m}^{2}$ adalah 0,34375 . Relatif risk (RR) kelompok IMT $\geq 25 \mathrm{~kg} / \mathrm{m}^{2}$ dibanding kelompok IMT $<25 \mathrm{~kg} / \mathrm{m}^{2}$ adalah 2,946, dapat diartikan bahwa subjek dengan IMT $\geq 25 \mathrm{~kg} / \mathrm{m}^{2}$ memiliki risiko terjadi MACE 2,946 kali lipat dibanding subjek dengan IMT $<25 \mathrm{~kg} / \mathrm{m}^{2}$.

\section{Pembahasan}

Gambaran demografi kelompok IMT $<25$ $\mathrm{kg} / \mathrm{m}^{2}$ dan kelompok IMT $\geq 25 \mathrm{~kg} / \mathrm{m}^{2}$ tidak berbeda secara bermakna yang ditandai dengan nilai $p>0,05$. Hasil ini menunjukkan bahwa kedua kelompok memiliki karakteristik yang sama untuk dibandingkan dalam analisis bivariat maupun multivariat. Usia rata-rata subjek 58 tahun sejalan dengan beberapa penelitian, di antaranya studi Saudi Project for Assessment of Coronary Events (SPACE) yang memperoleh hasil rata-rata usia pasien SKA adalah 58 tahun. Jenis kelamin paling dominan pada pasien SKA adalah laki-laki, sesuai dengan studi HP ACS Registry di India, SPACE di Arab Saudi, dan studi di RSUPN Dr. Cipto Mangunkusumo sebelumnya. ${ }^{16-18}$ Komorbid paling banyak adalah hipertensi. Diabetes melitus, dislipidemia, dan gagal ginjal kronis bukan merupakan komorbid dominan pasien SKA.

Satu-satunya variabel yang berhubungan dengan respon klopidogrel berupa MACE ialah IMT. Klopidogrel merupakan antiplatelet, berikatan dengan adenosine diphosphate (ADP) di permukaan platelet melalui reseptor P2Y12, yang menyebabkan hambatan irreversibel agregasi platelet. Studi membuktikan bahwa agregasi platelet (platelet aggregation; PA) pada berat badan berlebih (IMT $\geq 25 \mathrm{~kg} / \mathrm{m}^{2}$ ) lebih besar dibandingkan pada berat badan normal (IMT $<25 \mathrm{~kg} / \mathrm{m}^{2}$ ). ${ }^{15}$ PA yang lebih besar menyebabkan respon klopidogrel $75 \mathrm{mg}$ menjadi tidak optimal.

Diabetes melitus, hipertensi, dan dislipidemia diketahui merupakan prediktor MACE, namun dalam penelitian ini seluruh pasien dengan komorbid tertentu mendapatkan obat sesuai komorbid yang dimiliki. Hal ini menjadi alasan mengapa diabetes melitus, hipertensi dan dislipidemia tidak berhubungan dengan MACE dalam 60 hari pertama. ${ }^{19-21}$

Satu-satunya variabel yang berpengaruh terhadap MACE yaitu IMT, tidak ada variabel pengganggu yang mempunyai pengaruh bermakna terhadap MACE dengan nilai $p>0,05$ pada uji multivariat. Pengaruh yang dimiliki IMT terhadap MACE adalah searah, 
artinya semakin tinggi IMT, kemungkinan terjadinya MACE semakin besar pula. Studi farmakokinetik dan farmakodinamik tentang klopidogrel dilakukan terhadap pasien-pasien penyakit jantung koroner yang memiliki nilai IMT $<25 \mathrm{~kg} / \mathrm{m}^{2}$ dan IMT $\geq 25 \mathrm{~kg} / \mathrm{m}^{2}$. Pasien memperoleh terapi aspirin dan klopidogrel selama 10-14 hari. Parameter farmakokinetik yang diukur adalah area under curve (AUC) metabolit aktif klopidogrel yang menunjukkan bioavaibilitas. Diperoleh hasil bahwa pada pasien dengan IMT $\geq 25 \mathrm{~kg} / \mathrm{m}^{2}$,

Tabel 4 Hasil Tabulasi Silang Variabel Perancu dan MACE pada Pasien Sindrom Koroner Akut dengan Intervensi Koroner Perkutan di RSUPN Dr. Cipto Mangunkusumo Jakarta, 2018

\begin{tabular}{|c|c|c|c|}
\hline \multirow{3}{*}{ Variabel } & \multicolumn{2}{|c|}{ Kejadian MACE } & \multirow{3}{*}{ Nilai $p$} \\
\hline & Tidak Ada & IKP & \\
\hline & $\mathbf{n}(\%)$ & n(\%) & \\
\hline \multicolumn{4}{|l|}{ Jenis Kelamin } \\
\hline Laki-laki & $79(75,2)$ & $26(24,8)$ & 0,559 \\
\hline Perempuan & $16(84,2)$ & $3(15,8)$ & \\
\hline \multicolumn{4}{|l|}{ Usia } \\
\hline$<60$ tahun & $52(75,4)$ & $17(24 ., 6)$ & 0,877 \\
\hline$\geq 60$ tahun & $43(78,2)$ & $12(21,8)$ & \\
\hline \multicolumn{4}{|l|}{ Infark } \\
\hline Tidak ada & $66(76,7)$ & $20(23,3)$ & 1,000 \\
\hline Ada & $29(76,3)$ & $9(23,7)$ & \\
\hline \multicolumn{4}{|l|}{ Hipertensi } \\
\hline Tidak ada & $16(76,2)$ & $5(23,8)$ & 1,000 \\
\hline Ada & $79(76,7)$ & $24(23,3)$ & \\
\hline \multicolumn{4}{|l|}{ Diabetes Melitus } \\
\hline Tidak ada & $55(80,9)$ & $13(19,1)$ & 0,306 \\
\hline Ada & $40(71,4)$ & $16(18,6)$ & \\
\hline \multicolumn{4}{|l|}{ Dislipidemia } \\
\hline Tidak ada & $45(83,3)$ & $9(16,7)$ & 0,181 \\
\hline Ada & $50(71,4)$ & $20(18,6)$ & \\
\hline \multicolumn{4}{|l|}{ Gagal Ginjal Kronis } \\
\hline Tidak ada & $80(75,5)$ & $26(24,5)$ & 0,562 \\
\hline Ada & $15(83,3)$ & $3(16,7)$ & \\
\hline \multicolumn{4}{|l|}{ Status Merokok } \\
\hline Tidak merokok & $58(75,3)$ & $19(24,7)$ & 0,830 \\
\hline Merokok & $37(78,7)$ & $10(21,3)$ & \\
\hline \multicolumn{4}{|l|}{ Jenis Stent } \\
\hline Drug Eluting Stent (DES) & $94(76,4)$ & $29(23,6)$ & 1,000 \\
\hline Bare Metal Stent (BMS) & $1(100,0)$ & $0(0,0)$ & \\
\hline \multicolumn{4}{|l|}{ Jumlah Stent } \\
\hline 1 stent & $49(75,4)$ & $16(24,6)$ & 0,601 \\
\hline $2-3$ stent & $45(78,9)$ & $12(21,2)$ & \\
\hline$>3$ stent & $1(50,0)$ & $1(50,0)$ & \\
\hline \multicolumn{4}{|l|}{ Jenis Klopidogrel } \\
\hline Paten (Plavix®) & $39(70,9)$ & $16(29,1)$ & 0,260 \\
\hline Generik & $56(81,2)$ & $13(18,8)$ & \\
\hline \multicolumn{4}{|l|}{$\begin{array}{l}\text { Interaksi Obat Klopidogrel } \\
\text { dengan Omeprazole }\end{array}$} \\
\hline Tidak ada interaksi obat & $92(77,3)$ & $27(22,7)$ & 0,333 \\
\hline Interaksi obat mayor & $3(60,0)$ & $2(40,0)$ & \\
\hline
\end{tabular}


nilai AUC lebih kecil dibandingkan dengan pasien dengan IMT $<25 \mathrm{~kg} / \mathrm{m}^{2}$. Hal ini sejalan dengan studi terdahulu yang membuktikan bahwa pasien dengan IMT tinggi memiliki nilai rata-rata AUC lebih rendah dibanding pasien dengan IMT rendah. ${ }^{15}$

Keterbatasan penelitian ini adalah kejadian MACE berupa kematian tidak dapat teramati, hal ini disebabkan pengambilan rekam medis pasien meninggal dunia tidak dapat dilakukan. Kedua, penggunaan stent jenis Bare Metal Stent (BMS) sudah jarang sekali ditemukan di RSUPN Dr. Cipto Mangunkusumo; pada penelitian ini hanya ada satu subjek yang menggunakan BMS. Ketiga, penelitian ini merupakan penelitian restrospektif sehingga kepatuhan minum obat tidak dapat diamati secara langsung.

\section{Simpulan}

Demografi pasien kedua kelompok, yaitu kelompok pasien dengan IMT $<25 \mathrm{~kg} / \mathrm{m}^{2}$ dan $\geq 25 \mathrm{~kg} / \mathrm{m}^{2}$, tidak berbeda bermakna. Waktu rata-rata terjadinya MACE adalah 38 hari, dengan waktu tercepat 10 hari dan terlambat 60 hari. Hasil uji bivariat menunjukkan bahwa IMT memiliki hubungan yang signifikan terhadap MACE. Tidak ada variabel perancu yang berhubungan dengan MACE. Hasil uji multivariat menunjukkan bahwa IMT berpengaruh terhadap MACE dan tidak ada variabel perancu yang berpengaruh terhadap MACE. Dapat disimpulkan bahwa pasien dengan $\mathrm{IMT} \geq 25 \mathrm{~kg} / \mathrm{m}^{2}$ memiliki respon lebih rendah terhadap klopidogrel.

\section{Pendanaan}

Penelitian ini didanai oleh Lembaga Pengelola Dana Pendidikan (LPDP).

\section{Konflik Kepentingan}

Seluruh penulis menyatakan tidak terdapat potensi konflik kepentingan dengan penelitian, kepenulisan (authorship), dan atau publikasi artikel ini.

\section{Daftar Pustaka}

1. Loeffen R, Godschalk TC, Van Oerle R, Spronk HMH, Hackeng CM, Ten Berg $\mathrm{JM}$, et al. The hypercoagulable profile of patients with stent thrombosis. Heart. 2015;101(14):1126-32. doi: 10.1136/hea rtjnl-2014-306685.

2. Aghajani H, Alkamel A, Shafiee A, Jalali A, Nozari Y, Pourhosseini H, et al. Predictors of major adverse cardiac events following elective stenting of large coronary arteries. Indian Heart J. 2018;70(1):20-3. doi: 10.1 016/j.ihj.2017.06.011.

3. Tsai IT, Wang CP, Lu YC, Hung WC, $\mathrm{Wu} \mathrm{CC}, \mathrm{Lu} \mathrm{LF}$, et al. The burden of major adverse cardiac events in patients with coronary artery disease. BMC Cardiovasc Disord. 2017;17(1):1. doi: 10. 1186/s12872-016-0436-7

4. Duggal B, Subramanian J, Duggal M, Singh P, Rajivlochan M, Saunik S, et al. Survival outcomes post percutaneous coronary intervention: Why the hype about stent type? Lessons from a healthcare system in India. PLoS One. 2018;13(5):e0196830. doi: 10.1371/journ al.pone.0196830.

5. Farshidi H, Abdi A, Madani A, Moshiri S, Ghasemi A, Cardiologist I, et al. Major adverse cardiovascular event (MACE) after percutaneous coronary intervention in one-year follow- up study. Electroic Physician. 2018;10(2):6383-9. doi: 10.19 082/6383

6. Yin D, Li J, Yang YJ, Wang Y, Zhao YY, You SJ, et al. Nine-year clinical outcomes of drug-eluting stents vs. bare metal stents for large coronary vessel lesions. J Geriatr Cardiol. 2017;14(1):35-41. doi: 1 0.11909/j.issn.1671-5411.2017.01.009 
7. Lee MG, Jeong MH, Lee KH, Park KH, Sim DS, Yoon HJ, et al. Prognostic impact of diabetes mellitus and hypertension for mid-term outcome of patients with acute myocardial infarction who underwent percutaneous coronary intervention. J Cardiol. 2012;60(4):257-63. doi: 10.1016 /j.jjcc.2012.06.003.

8. Jeong YA, Jeong MH, Jeong HC, Ahn Y, Kim YJ, Kim CJ, et al. Impact of smoking on clinical outcomes in female patients with acute myocardial infarction. Korean Circ J. 2015;45(1):22. doi: 10.4070/kcj.2 015.45.1.22

9. Fu C, Wang H, Wei Q, He C, Zhang C. Effects of rehabilitation exercise on coronary artery after percutaneous coronary intervention in patients with coronary heart disease: A systematic review and meta-analysis. Disabil Rehabil. 2018;10:1-7. doi: 10.1080/09638288.2018.

10. Que B, Wang C, Ai H, Zhang X, Wang M, Nie S. Residual dyslipidemia leads to unfavorable outcomes in patients with acute coronary syndrome after percutaneous coronary intervention. Stem Cells Int. 2016;2016:6175948. doi: 10.115 5/2 016/6175948.

11. Das SR, Alexander KP, Chen AY, PowellWilley P, Roe MT, de Lemos JA. Impact of body weight and extreme obesity on the presentation, treatment, and in-hospital outcomes of 50,149 patients with STSegment elevation myocardial infarction results from the NCDR (National Cardiovascular Data Registry). Am Coll Cardiol Found. 2011;58(25):2642-50. doi: 10.1016/j.jacc.2011.09.030.

12. Amsterdam EA, Wenger NK, Brindis RG, Casey DE, Ganiats TG, Holmes DR, et al. 2014 AHA/ACC guideline for the management of patients with nonST-elevation acute coronary syndromes: A report of the American college of cardiology/American heart association task force on practice guidelines. J Am Coll Cardiol. 2014;64(24):e139-228. doi: 10.1016/j.jacc.2014.09.017.

13. Perhimpunan Dokter Spesialis Kardiovaskular Indonesia. Pedoman tata laksana sindrom koroner akut. 2018.

14. Jiang XL, Samant S, Lesko LJ, Schmidt S. Clinical pharmacokinetics and pharmacodynamics of clopidogrel. Clin Pharmacokinet. 2015;54(2):147-66. doi: 10.1007/s40262-014-0230-6

15. Wagner H, Angiolillo DJ, Ten Berg JM, Bergmeijer TO, Jakubowski JA, Small DS, et al. Higher body weight patients on clopidogrel maintenance therapy have lower active metabolite concentrations, lower levels of platelet inhibition, and higher rates of poor responders than low body weight patients. J Thromb Thrombolysis. 2014;38(2):127-36. doi: 10. 1007/s11239-013-0987-8.

16. Al-saif SM, Alhabib KF, Ullah A, Hersi A, Alfaleh H, Alnemer K, et al. Age and its relationship to acute coronary syndromes in the Saudi Project for Assessment of Coronary Events (SPACE) registry: The SPACE age study. J Saudi Heart Assoc. 2011;24(1):9-16. doi: 10.1016/j.jsha.201 1.08 .001

17. Chand P, Merwaha R, Panday D, Chauhan V, Guleri R. Multicenter HP ACS Registry. Indian Heart J. 2015;68(2):118-27. doi: 10.1016/j.ihj.2015.07.027.

18. Meutia RS, Nasution SA, Makmun LH, Dewiastry E. Uji validasi simple risk index dan evaluation of methods and management of acute coronary events dalam memprediksi mortalitas pasien sindrom koroner akut di Intensive Coronary Care Unit Rumah Sakit Cipto Mangunkusumo. J Penyakit Dalam Indones. 2017;4(4):178-87. doi: 10.7454/jpdi.v4i 4.146

19. Kim YH, Kim B. Two-year outcomes of statin therapy in patients with acute 
myocardial infarction with or without dyslipidemia after percutaneous coronary intervention in the era of new- generation drug-eluting stents within Korean population: Data from the Korea Acute Myocardial Infarction Registry. Catheter Cardiovasc Interv. 2019;93(7):1264-1275. doi: 10.1002/ccd.27985.

20. Byun JK, Choi BG, Rha SW, Choi $\mathrm{SY}$, Jeong $\mathrm{MH}$; Other Korea Acute Myocardial Infarction Registry (KAMIR) investigators. Comparison of angiotensinconverting enzyme inhibitors and angiotensin II receptor blockers in patients with diabetes mellitus and non-ST- segment elevation myocardial infarction who underwent successful percutaneous coronary intervention. Atherosclerosis. 2018;277:130-5. doi: 10.1016/j.atheroscl erosis.2018.08.038.

21. Eitel I, Hintze S, De Waha S, Fuernau G, Lurz P, Desch S, et al. Prognostic impact of hyperglycemia in nondiabetic and diabetic patients with ST-elevation myocardial infarction: Insights from contrast-enhanced magnetic resonance imaging. Circ Cardiovasc Imaging. 2012; 5(6):708-18. doi: 10.1161/CIRCIMAGI NG.112.974998. 